\title{
The role of inhaled methoxyflurane in acute pain management
}

This article was published in the following Dove Press journal: Open Access Emergency Medicine

\author{
Keith M Porter' \\ Anthony D Dayan² \\ Sara Dickerson ${ }^{3}$ \\ Paul M Middleton ${ }^{4,5}$ \\ 'Trauma Department, University \\ Hospitals Birmingham NHS \\ Foundation Trust, Queen Elizabeth \\ Hospital, Birmingham, UK; \\ ${ }^{2}$ Independent Consultant, London, \\ UK; ${ }^{3}$ Medical Affairs, Mundipharma \\ International Limited, Cambridge, \\ UK; ${ }^{4}$ Emergency Medicine Research \\ Unit, Liverpool Hospital, Sydney, \\ NSW, Australia; ${ }^{5}$ Distributed Research \\ in Emergency and Acute Medicine \\ (DREAM) Collaboration, Sydney, \\ NSW, Australia
}

\begin{abstract}
Methoxyflurane is an inhaled analgesic administered via a disposable inhaler which has been used in Australia for over 40 years for the management of pain associated with trauma and for medical procedures in children and adults. Now available in 16 countries worldwide, it is licensed in Europe for moderate to severe pain associated with trauma in conscious adults, although additional applications are being made to widen the range of approved indications. Considering these ongoing developments, we reviewed the available evidence on clinical usage and safety of inhaled analgesic methoxyflurane in trauma pain and in medical procedures in both adults and children. Published data on methoxyflurane in trauma and procedural pain show it to be effective, well tolerated, and highly rated by patients, providing rapid onset of analgesia. Methoxyflurane has a well-established safety profile; adverse events are usually brief and selflimiting, and no clinically significant effects on vital signs or consciousness levels have been reported. Nephrotoxicity previously associated with methoxyflurane at high anesthetic doses is not reported with low analgesic doses. Although two large retrospective comparative studies in the prehospital setting showed inhaled analgesic methoxyflurane to be less effective than intravenous morphine and intranasal fentanyl, this should be balanced against the administration, supervision times, and safety profile of these agents. Given the limitations of currently available analgesic agents in the prehospital and emergency department settings, the ease of use and portability of methoxyflurane combined with its rapid onset of effective pain relief and favorable safety profile make it a useful nonopioid option for pain management. Except for the STOP! study, which formed the basis for approval in trauma pain in Europe, and a few smaller randomized controlled trials (RCTs), much of the available data are observational or retrospective, and further RCTs are currently underway to provide more robust data.
\end{abstract}

Keywords: analgesia, clinical safety, Penthrox, procedural pain, review, trauma

\section{Introduction}

Methoxyflurane is a fluorinated hydrocarbon anesthetic introduced to the market by Abbott Laboratories as Penthrane in the early 1960s (Figure 1). Methoxyflurane showed some advantages over other volatile anesthetics available at the time, including maintenance of cardiovascular stability and analgesia that extended into the postoperative period, ${ }^{1,2}$ and by 1970 , it had been used in 10 million patients. ${ }^{3}$ Since methoxyflurane was found to have analgesic properties at subanesthetic doses, ${ }^{4}$ Abbott Laboratories developed a disposable inhaler (the Analgizer, $15 \mathrm{~mL}$ dose) for the self-administration of methoxyflurane for pain relief in minor surgical procedures and obstetrics in the late 1960s. However, in 1966, the first report of postoperative nephrotoxicity associated
Mundipharma International Limited, 194

Cambridge Science Park, Milton Road

Cambridge CB4 OAB, UK

Tel +44 I2234242II

Email sara.dickerson@mundipharma.com 
with methoxyflurane emerged $;^{5}$ subsequent clinical and laboratory research showed that the nephrotoxicity was a dose-related complication caused by fluoride ions (and possibly dichloroacetic acid) produced by O-demethylation of methoxyflurane.$^{6-9}$ Further reports of nephrotoxicity followed during the 1970s, ${ }^{6,10-12}$ and the use of methoxyflurane as an anesthetic subsequently declined as other, better-tolerated agents became available. Analgizer and Penthrane were voluntarily withdrawn from the market in 1974 and 2001, respectively, and in 2005, the US Food and Drug Administration determined a final withdrawal to prevent new drug applications for methoxyflurane for anesthesia because of the risk of nephrotoxicity. ${ }^{13}$

Although methoxyflurane has been withdrawn for use as an anesthetic agent, low-dose methoxyflurane delivered via a hand-held inhaler (Figure 2; Penthrox, $3 \mathrm{~mL}$ dose; Medical Developments International, Scoresby, Australia) has been continued to be used widely in Australia and New Zealand since 1975, where it is licensed for use in both adults and children as an analgesic for pain associated with trauma and for pain associated with brief medical procedures. ${ }^{14,15}$ Methoxyflurane liquid is added to the inhaler via a oneway valve and is absorbed by a polypropylene wick; once absorbed, the liquid vaporizes and the patient inhales the vapor through the mouthpiece. The patient exhales back into the mouthpiece, so that any exhaled methoxyflurane is captured by the activated charcoal (AC) chamber that adsorbs methoxyflurane and prevents fugitive emissions resulting in occupational exposure; stronger analgesia is delivered by occlusion of the diluter hole on the $\mathrm{AC}$ chamber with a finger. One inhaler ( $3 \mathrm{~mL}$ methoxyflurane) provides $25-30$ minutes of analgesia with continuous use; intermittent use extends the duration of action, and the STOP! study indicated a duration of $\sim 54$ minutes per vial with intermittent use. ${ }^{18}$ If required, a second vial of methoxyflurane may be used, with a total dose not exceeding $6 \mathrm{~mL}$ (two vials) in 1 day or 15 $\mathrm{mL}$ (five vials) in 1 week. $^{16}$

More recently, low-dose methoxyflurane has been approved in Europe for the emergency relief of moderate to severe pain associated with trauma in conscious adult patients, ${ }^{16}$ as well as in other territories including South Africa, the Gulf Area, Eastern Europe, and Latin America, with a total of over 6 million administrations worldwide to date. ${ }^{17}$ Further studies are underway to broaden the list of approved indications outside of Australia and New Zealand. Given the emergence of low-dose methoxyflurane across Europe as an analgesic, this article reviews the clinical usage of methoxyflurane as an analgesic in both trauma pain and in medical procedures in both adults and children with respect to safety, efficacy, and satisfaction.

\section{Search methods}

Although methoxyflurane was first used as an analgesic in the late 1960s, historical data for the use of inhaled methoxyflurane via other devices are not included only because the time frame for search was limited to the last 20 years to capture current medical practice. Relevant publications were identified via a literature search performed using

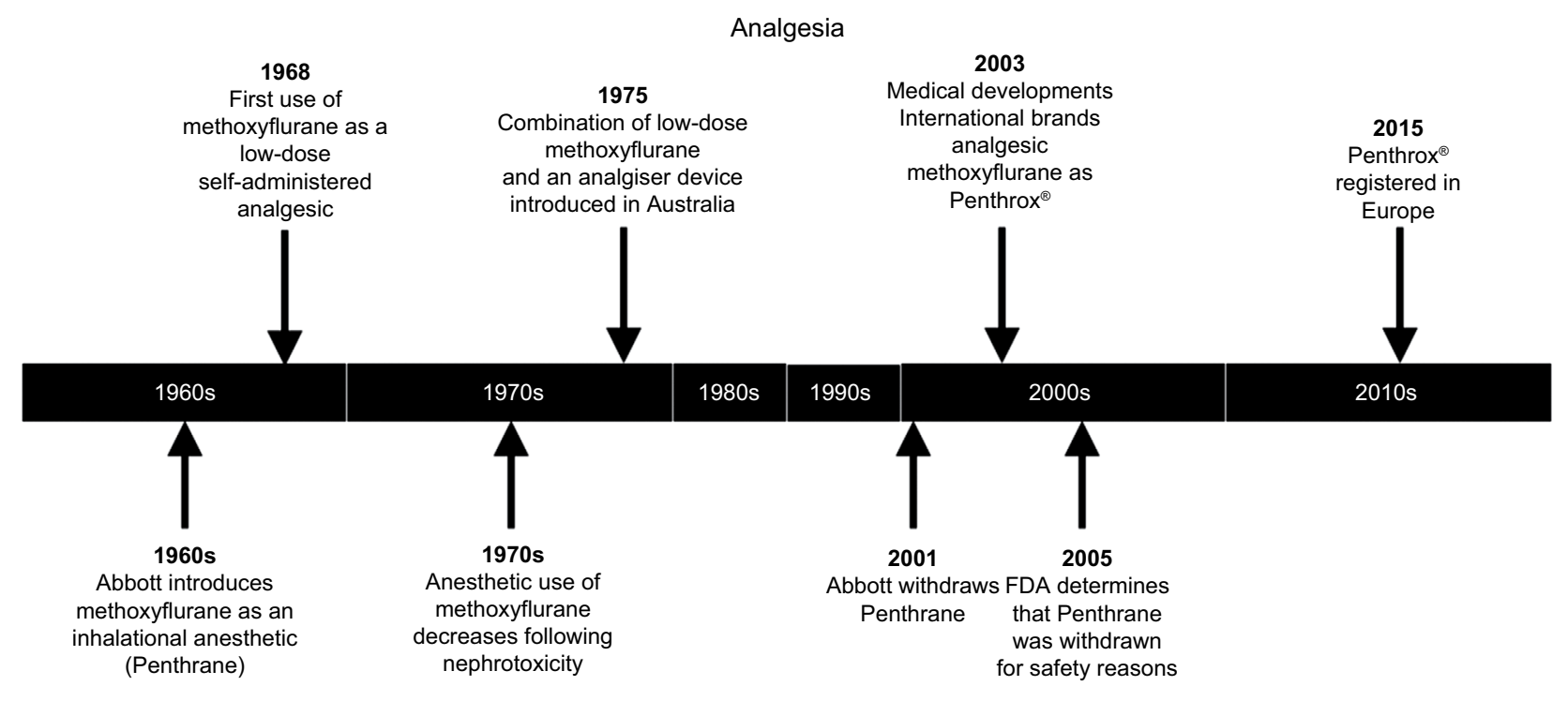

Anaesthesia

Figure I Timeline of methoxyflurane use.

Abbreviation: FDA, US Food and Drug Administration. 
PubMed to search the MEDLINE online database on June 6, 2018, and via concomitant searches on Google Scholar and EMBASE, using the search terms "methoxyflurane" or "Penthrox" or "Penthrane" and "analgesia" or "analgesic" or "pain." English-language articles published within the past 20 years returned by this search were screened for relevance to the use of inhaled methoxyflurane, and additional data from congress presentations and supplements were included where appropriate. Retrieved publications were screened for relevance against the inclusion/exclusion criteria presented in Table 1. In total, 21 publications presenting primary research data on humans were selected for inclusion in this review (Tables 2-4). In addition to the literature published in scientific journals, a "gray" literature search was conducted to ensure that no relevant data sources were excluded. This search also allowed for the identification of data from freely available sources. Internet-based sources were searched using no predefined search criteria, to ensure all key sources of information were exhausted.

\section{Australian experience with methoxyflurane}

Inhaled methoxyflurane has been used as an analgesic for over 40 years by Australian ambulance and air ambulance
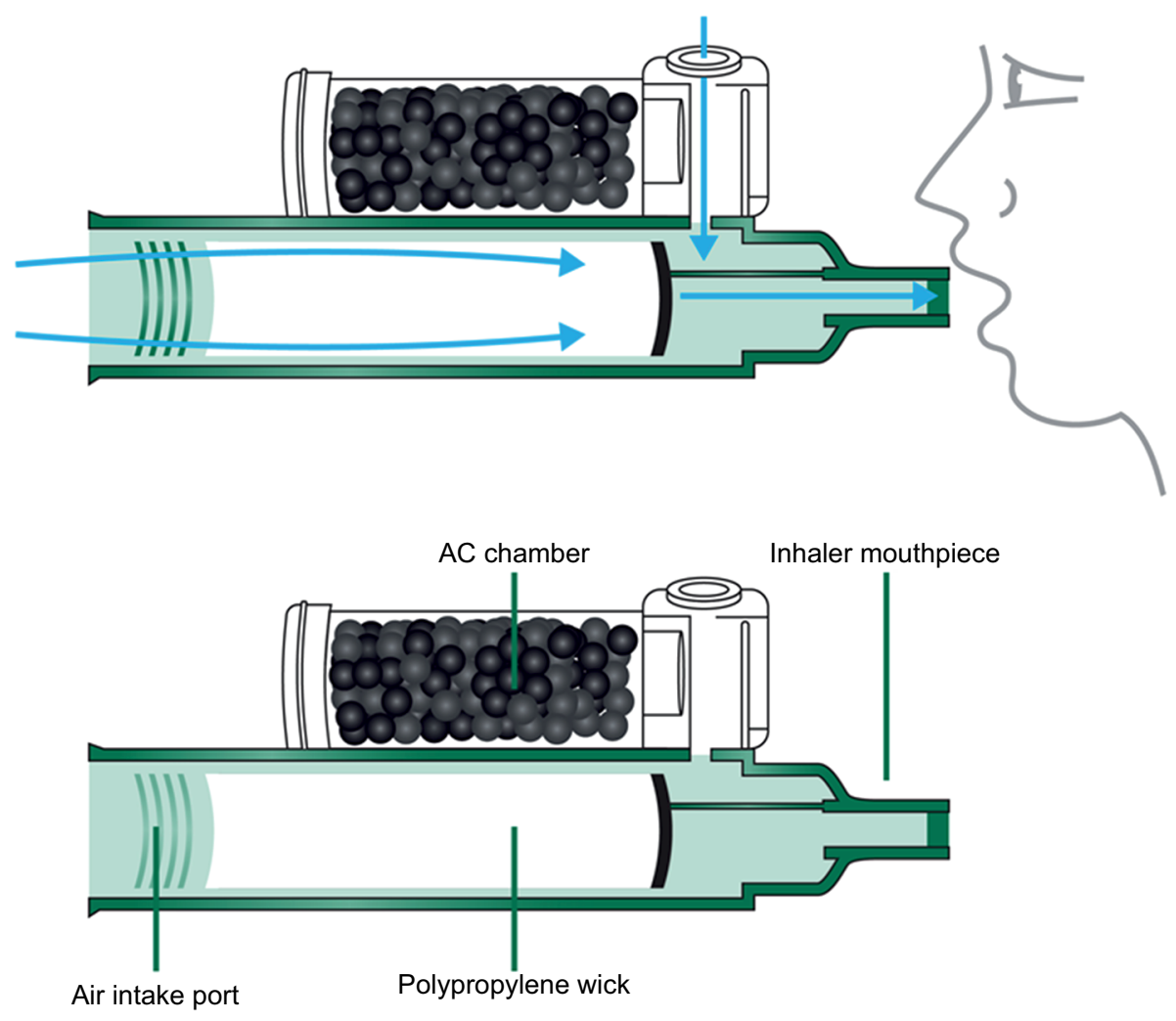

Figure 2 The Penthrox ${ }^{\circledR}$ inhaler.

Abbreviation: AC, activated charcoal.

Table I Inclusion and exclusion criteria used in the review of available literature

\begin{tabular}{|l|l|}
\hline Inclusion criteria & Exclusion criteria \\
\hline $\begin{array}{l}\text { Publications were included that } \\
\text { - Discussed the clinical application of inhaled methoxyflurane at } \\
\text { analgesic doses in pain or medical procedures } \\
\text { - Related solely to the treatment of trauma pain in specific patient } \\
\text { groups including pediatrics, elderly }\end{array}$ & $\begin{array}{l}\text { Publications were excluded that } \\
\text { - Discussed the use of inhaled methoxyflurane at anesthetic dosing } \\
\text { - Related to the treatment patterns and pain management of } \\
\text { moderate to severe trauma pain }\end{array}$ \\
$\begin{array}{l}\text { - Explored the safety or inhaled analgesic methoxyflurane with } \\
\text { respect to health and safety of healthcare workers and patients }\end{array}$ & $\begin{array}{l}\text { - Did not report on pain or treatment for pain (emergency or } \\
\text { procedural) }\end{array}$ \\
& $\begin{array}{l}\text { - Focused on long-term or chronic pain } \\
\text { Related solely to patients whose treatment would be outside } \\
\text { the legal licensed indication for inhaled analgesic methoxyflurane } \\
\text { including pregnant patients or patients with reduced consciousness }\end{array}$
\end{tabular}


Table 2 Overview of studies of methoxyflurane in patients with trauma pain

\begin{tabular}{|c|c|c|c|c|c|}
\hline Reference & $\begin{array}{l}\text { Evidence } \\
\text { level }\end{array}$ & Design & $\begin{array}{l}\text { Number of } \\
\text { patients } \\
\text { (received } \\
\text { analgesic } \\
\text { methoxyflurane) }\end{array}$ & $\begin{array}{l}\text { Age } \\
\text { restriction } \\
\text { (years) }^{\mathrm{a}}\end{array}$ & Efficacy results \\
\hline \multicolumn{6}{|c|}{ Registration trial } \\
\hline $\begin{array}{l}\text { Coffey et al } \\
(2014)^{25, b}\end{array}$ & 1 & $\begin{array}{l}\text { Randomized, } \\
\text { double-blind, } \\
\text { placebo- } \\
\text { controlled, } \\
\text { multicenter } \\
\text { study }\end{array}$ & $300(149)$ & $\geq 12$ & $\begin{array}{l}\text { - Significant reduction in } \mathrm{I} 00 \mathrm{~mm} \text { VAS pain scores } \\
\text { compared with placebo at } 5, \mathrm{I}, \mathrm{I}, \mathrm{I} \text {, and } 20 \text { minutes } \\
(P<0.000 \mathrm{I}) \\
\text { - Greatest estimated treatment effect of }-18.5 \mathrm{~mm} \\
\text { seen at } \mathrm{I} 5 \text { minutes } \\
\text { - Pain relief within } \mathrm{I} 0 \text { inhalations for } 84.6 \% \text { receiving } \\
\text { methoxyflurane and } 5 \mathrm{I} \% \text { receiving placebo } \\
\text { - } 2 \text { patients ( } \mathrm{I} .3 \%) \text { needed rescue medication vs } 25 \\
\text { ( } 16.8 \% \text { in the placebo group; } P=0.0002) \\
\text { - Global medication performance rated significantly } \\
\text { better for methoxyflurane than placebo }(P<0.000 \mathrm{I})\end{array}$ \\
\hline \multicolumn{6}{|c|}{ Emergency department use } \\
\hline $\begin{array}{l}\text { Gillis et al } \\
(2008)^{28, b, c} \\
\text { Konkayev } \\
(2013)^{29}\end{array}$ & 5 & $\begin{array}{l}\text { Observational } \\
\text { case series } \\
\text { Prospective } \\
\text { single center } \\
\text { cohort study vs } \\
\text { IM tramadol }\end{array}$ & $\begin{array}{l}(59) \\
40(20)\end{array}$ & $\begin{array}{l}>3 \\
>18\end{array}$ & $\begin{array}{l}\text { - VNRS pain scores significantly reduced by } 2.3 \text { at I5 } \\
\text { minutes and } 3.3 \text { at } 30 \text { minutes }(P<0.025) \\
\text { - After } 5 \text { minutes: } \\
\circ \text { Pain scores had reduced from } 4.1 \text { to } 0.6 \text { with } \\
\text { methoxyflurane and from } 5.5 \text { to } 4.2 \text { with tramadol } \\
\circ \text { Anxiety scores had reduced from } 3.9 \text { to } 0.4 \text { with } \\
\text { methoxyflurane and from } 4.6 \text { to } 3.4 \text { with tramadol } \\
\text { - After } 30 \text { minutes, pain and anxiety scores were } 0.2 \text { in } \\
\text { both groups }\end{array}$ \\
\hline \multicolumn{6}{|c|}{ Prehospital use } \\
\hline $\begin{array}{l}\text { Buntine et al } \\
(2007)^{26}\end{array}$ & 5 & $\begin{array}{l}\text { Observational } \\
\text { case series }\end{array}$ & (83) & $>18$ & $\begin{array}{l}\text { - Mean ( } \pm \text { SE) reduction in VNRS-II scores } \\
\circ 5 \text { minutes: } 2.47( \pm 0.24) \\
\circ \text { Arrival at hospital: } 3.21 \text { ( } \pm 0.24) \text { by arrival at hospital } \\
\text { (both } P<0.000 \text { I vs baseline) } \\
\text { - } 72 \% \text { of patients and } 82 \% \text { of paramedics were satisfied } \\
\text { with the level of analgesia }\end{array}$ \\
\hline $\begin{array}{l}\text { Oxer and } \\
\text { Wilkes } \\
(2007)^{30, b, c}\end{array}$ & 3 & $\begin{array}{l}\text { Retrospective } \\
\text { study vs IN } \\
\text { fentanyl }\end{array}$ & $13,963(10,706)$ & NR & $\begin{array}{l}\text { For both agents, }>90 \% \text { of patients reported good or } \\
\text { partial pain relief }\end{array}$ \\
\hline $\begin{array}{l}\text { Middleton } \\
\text { et al }(2010)^{27}\end{array}$ & 3 & $\begin{array}{l}\text { Retrospective } \\
\text { study vs IV } \\
\text { morphine and } \\
\text { IN fentanyl }\end{array}$ & $42,844(19,235)$ & $16-100$ & $\begin{array}{l}\text { - Mean }(95 \% \mathrm{Cl}) \text { reduction in VNRS-II: } 3.2(3.1,3.2) \text { for } \\
\text { methoxyflurane; } 4.5(4.5,4.6) \text { for morphine; } 4.5(4.4 \text {, } \\
\text { 4.6) for fentanyl } \\
\text { - Effective analgesia ( } \geq 30 \% \text { reduction in pain } \\
\text { severity) achieved by } 59.1 \% \text { of patients receiving } \\
\text { methoxyflurane, } 81.8 \% \text { receiving morphine, } 80.0 \% \\
\text { receiving fentanyl }\end{array}$ \\
\hline $\begin{array}{l}\text { Lim et al } \\
(2016)^{31, c}\end{array}$ & 1 & $\begin{array}{l}\text { Prospective, } \\
\text { cluster- } \\
\text { randomized, } \\
\text { crossover study } \\
\text { vs IM tramadol }\end{array}$ & $311(135)$ & $>16$ & $\begin{array}{l}\text { - Median (IQR) reduction in pain scores: } \\
\circ \text { At } 5 \text { minutes: } 3.0(-1.3,4.8) \text { with methoxyflurane vs } \\
\text { I.0 }(0.0,2.0) \text { with tramadol } \\
\circ \text { At } 10 \text { minutes: } 2.0(-1.0,3.0) \text { with methoxyflurane } \\
\text { vs } 1.0(0.0,2.0) \text { with tramadol } \\
\text { - Median (IQR) time to effective analgesia: } 3.0(-1.0,5.0) \\
\text { minutes with methoxyflurane vs } 5.0(-3.0,5.0) \text { minutes } \\
\text { with tramadol } \\
\text { - Median (IQR) time to administer first dose: } 9.0(-6.0 \text {, } \\
\text { 14.0) minutes with methoxyflurane vs II }(-8.0,15.0) \\
\text { minutes with tramadol }\end{array}$ \\
\hline
\end{tabular}

Notes: Evidence level: Level I=evidence from meta-analysis or randomized clinical trials, Level 2=evidence from individual studies, Level $3=$ evidence from quasi-experimental studies, Level $4=e v i d e n c e$ from descriptive studies, Level $5=$ evidence from case reports, Level $6=$ specialist opinion. ${ }^{a}$ As stipulated in inclusion criteria. ${ }^{b}$ Mixed population of adults and children. 'Only available as an abstract.

Abbreviations: IQR, interquartile range; IV, intravenous; IN, intranasal; NR, not reported; VAS, visual analog scale; VNRS, verbal numeric rating scale; IM, intramuscula.. 
Table 3 Overview of studies in pediatric patients

\begin{tabular}{|c|c|c|c|c|c|}
\hline Reference & $\begin{array}{l}\text { Evidence } \\
\text { level }\end{array}$ & Design & $\begin{array}{l}\text { Number of } \\
\text { patients } \\
\text { (received } \\
\text { Penthrox) }\end{array}$ & $\begin{array}{l}\text { Age } \\
\text { restriction } \\
\text { (years) }^{\mathrm{a}}\end{array}$ & Efficacy results \\
\hline \multicolumn{6}{|l|}{ Prehospital } \\
\hline $\begin{array}{l}\text { Babl et al } \\
(2006)^{33} \\
\text { Bendall et al } \\
(2011)^{34}\end{array}$ & 4 & $\begin{array}{l}\text { Prospective } \\
\text { observational case } \\
\text { series } \\
\text { Retrospective, } \\
\text { comparative study vs } \\
\text { IV morphine and IV } \\
\text { fentanyl }\end{array}$ & $3,3 \mid 2(2,093)$ & $5-15$ & $\begin{array}{l}\text { - Mean }(95 \% \mathrm{Cl}) \text { VNRS pain scores (rated by paramedics): } \\
\circ \text { At administration: } 7.9(7.5,8.3) \\
\circ \text { At } 10 \text { minutes: } 3.2(2.8,3.7) \\
\text { - } 88.5 \% \text { of paramedics and } 91.3 \% \text { of parents were satisfied } \\
\text { to very satisfied with the level of analgesia } \\
\text { - Effective analgesia (VNRS-II reduced by } \geq 30 \%) \text { for } 78.3 \% \\
\text { of patients receiving methoxyflurane, } 87.5 \% \text { receiving } \\
\text { morphine and } 89.5 \% \text { receiving fentanyl }\end{array}$ \\
\hline \multicolumn{6}{|c|}{ Emergency department } \\
\hline $\begin{array}{l}\text { Chin et al } \\
(2002)^{35, b} \\
\text { Babl et al } \\
(2007)^{32, c}\end{array}$ & 1 & $\begin{array}{l}\text { Randomized, double- } \\
\text { blind, placebo- } \\
\text { controlled study } \\
\text { Prospective } \\
\text { observational case } \\
\text { series }\end{array}$ & (14) & $5-18$ & $\begin{array}{l}\text { - Mean reduction in pain score (faces scale) between } 0 \text { and } \\
10 \text { minutes: } 4.0 \text { for methoxyflurane and } I .3 \text { for placebo } \\
(P<0.05) \\
\text { - Four patients with trauma receiving methoxyflurane for } \\
\text { bridging analgesia experienced large reductions in pain } \\
\text { score } \\
\text { - Six patients undergoing medical procedures had } \\
\text { satisfactory analgesia }\end{array}$ \\
\hline
\end{tabular}

Notes: Evidence level: Level I=evidence from meta-analysis or randomized clinical trials, Level 2=evidence from individual studies, Level $3=e v i d e n c e$ from quasi-experimental studies, Level $4=$ evidence from descriptive studies, Level $5=$ evidence from case reports, Level $6=$ specialist opinion. ${ }^{\mathrm{a} A s}$ specified in the inclusion criteria. ${ }^{\mathrm{b}} \mathrm{Abstract}$ only. cMixed population of trauma and procedural pain (all other studies were in trauma pain only).

Abbreviations: IN, intranasal; IV, intravenous; VNRS, verbal numerical rating scale.

services, surf life savers, and emergency departments (EDs). It is also used in other situations where rapid first response analgesia is needed, such as on ski fields, pitch-side, in mines, and on military battlefields, where the most common form of battlefield analgesia, intramuscular (IM) morphine, is associated with limitations in terms of side effects, slow speed of onset in some patients, and mechanical failure of the autoinjector. ${ }^{19}$ Proven stability over a wide temperature range $\left(-20^{\circ} \mathrm{C}\right.$ to $\left.40^{\circ} \mathrm{C}\right)$ and an easy-to-use inhaler have made analgesic methoxyflurane suitable for emergency situations in extreme environments or in mass emergency situations where multiple casualties may need to be treated in a short period of time with limited personnel. Analgesic methoxyflurane has been employed as a useful bridging analgesic prior to, or during, morphine administration, or in combination with morphine when insufficient analgesia is obtained ${ }^{19}$ and is included in clinical guidelines as a recommended treatment option for pain management. ${ }^{20}$

In the Queensland Ambulance Service and the Australian Capital Territory Ambulance Service, and for St John Ambulance Australia (Western Australia), methoxyflurane is the first-line analgesic before intranasal (IN) fentanyl and morphine ${ }^{21-23}$ and the second-line treatment within
Ambulance Victoria, for moderate to severe pain following IN fentanyl and morphine. ${ }^{24}$ In the clinical experience of the authors, methoxyflurane may be used as a second- or third-line analgesic when other therapy is ineffective but is more frequently used either as a first-line analgesic alone or while other agents are being prepared. Much of the published real-world and clinical trial evidence discussed later in this review originates from Australia, reflecting that country's depth of experience with methoxyflurane.

As inhaled analgesic methoxyflurane becomes available for European prescribing, the question arises as to what data are available to support the use of inhaled analgesic methoxyflurane in acute trauma pain. Outside Europe, as described above, inhaled analgesic methoxyflurane is also used for pain associated with medical procedures and in children; ${ }^{14,15}$ although this is not yet approved in Europe, there is clearly a need to also understand these data.

\section{Inhaled analgesic methoxyflurane in trauma-associated pain}

The historic use of methoxyflurane as an analgesic in the 1960s/1970s was achieved using a range of devices, often those whose original purpose was anesthesia, and at higher 
Table 4 Overview of studies in medical procedures

\begin{tabular}{|c|c|c|c|c|c|}
\hline Reference & $\begin{array}{l}\text { Evidence } \\
\text { level }\end{array}$ & Design & $\begin{array}{l}\text { Number of } \\
\text { patients } \\
\text { (received } \\
\text { analgesic } \\
\text { methoxyflurane) }\end{array}$ & $\begin{array}{l}\text { Age } \\
\text { restriction } \\
\text { (years) }^{\mathrm{a}}\end{array}$ & Efficacy results \\
\hline \multicolumn{6}{|l|}{ Colonoscopy } \\
\hline $\begin{array}{l}\text { Nguyen et al } \\
(2015)^{50}\end{array}$ & 1 & $\begin{array}{l}\text { Prospective, } \\
\text { multicenter, } \\
\text { randomized study vs } \\
\text { IV midazolam plus } \\
\text { fentanyl } \\
\text { Prospective, single- } \\
\text { center, comparative } \\
\text { study vs AADS. } \\
\text { Patients were } \\
\text { required to have } \\
\text { morbid obesity or } \\
\text { obstructive sleep } \\
\text { apnea }\end{array}$ & 140 (85) & I8-75 & $\begin{array}{l}\text { - Pain and anxiety scores similar between the two } \\
\text { groups before, during, and after the procedure } \\
\text { - Methoxyflurane associated with a shorter } \\
\text { recovery time: patients discharged on average } 15 \\
\text { minutes earlier than those receiving IV sedation } \\
\text { - Overall satisfaction score for methoxyflurane: } \\
94 / 100 \\
\text { - Methoxyflurane associated with shorter total } \\
\text { procedural time than AADS ( } 24 \pm I \text { vs } 52 \pm I \\
\text { minutes; } P<0.00 I \text { ) } \\
\text { - Discharge from hospital occurred earlier with } \\
\text { methoxyflurane than with AADS ( } 27.2 \pm 2 \text { vs } 97 \pm 5 \\
\text { minutes; } P<0.000 I) \\
\text { - } 28 / 34 \text { patients }(82 \%) \text { who received } \\
\text { methoxyflurane, and had received AADS } \\
\text { previously, said they would prefer to receive } \\
\text { methoxyflurane in the future }\end{array}$ \\
\hline \multicolumn{6}{|c|}{ Prostate biopsy } \\
\hline $\begin{array}{l}\text { Grummet et al } \\
(2012)^{45}\end{array}$ & 2 & $\begin{array}{l}\text { Prospective, single- } \\
\text { center, single-arm } \\
\text { study }\end{array}$ & (42) & NR & $\begin{array}{l}\text { - Median VRS pain score immediately after the } \\
\text { procedure was } 3 \text { (IQR 2-5) } \\
\text { - All patients stated they would be happy to } \\
\text { undergo the procedure again }\end{array}$ \\
\hline $\begin{array}{l}\text { Lee and Woo } \\
(2015)^{47}\end{array}$ & 2 & $\begin{array}{l}\text { Prospective, single- } \\
\text { center, single-arm } \\
\text { study }\end{array}$ & $(64)$ & 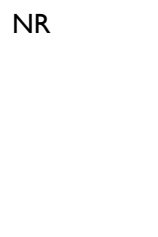 & $\begin{array}{l}\text { Median pain scores ( } 10 \mathrm{~cm} \text { VAS) were } 2.0,2.4 \text {, } \\
\text { and } 3.0 \text { during digital rectal examination, probe } \\
\text { insertion, and needle biopsy, respectively } \\
\text { - } 30 \text { patients }(46.8 \%) \text { said they would undergo the } \\
\text { procedure using the inhaler again; } 9 \text { (14\%) said } \\
\text { they would prefer local anesthetic }\end{array}$ \\
\hline $\begin{array}{l}\text { Huang et al } \\
(2016)^{46}\end{array}$ & 2 & $\begin{array}{l}\text { Prospective, } \\
\text { single center, } \\
\text { comparative study vs } \\
\text { methoxyflurane plus } \\
\text { PILA }\end{array}$ & $\begin{array}{l}72(42 \\
\text { methoxyflurane } \\
\text { alone; } 30 \\
\text { methoxyflurane+ } \\
\text { PILA) }\end{array}$ & NR & $\begin{array}{l}\text { - Median postbiopsy VRS pain intensity was } 3 \text { (IQR } \\
2-5) \text { in the methoxyflurane group vs } 2(\text { IQR I-3) } \\
\text { in the methoxyflurane+PILA group }(P=0.0 \mid 4)\end{array}$ \\
\hline \multicolumn{6}{|c|}{ Bone marrow biopsy } \\
\hline $\begin{array}{l}\text { Spruyt et al } \\
(2014)^{43}\end{array}$ & 2 & $\begin{array}{l}\text { Single center, } \\
\text { randomized, double- } \\
\text { blind, placebo- } \\
\text { controlled study. } \\
\text { Patients in both } \\
\text { groups also received } \\
\text { local anesthesia }\end{array}$ & $97(49)$ & $\geq 18$ & $\begin{array}{l}\text { - Mean NRS }( \pm S D) \text { scores for "worst pain": } \\
\text { ○ Overall: } 4.90( \pm 2.07) \text { for methoxyflurane vs } 6.0 \\
( \pm 2.24) \text { for placebo }(P=0.0 \mathrm{II}) \\
\text { ○ During aspiration: } 3.3( \pm 2.0) \text { for methoxyflurane } \\
\text { vs } 5.0( \pm 2.4) \text { for placebo }(P<0.00 \mathrm{I}) \\
\text { - } 49 \% \text { of patients receiving methoxyflurane rated } \\
\text { the medication as "very good" or "excellent" vs } \\
\text { 16.5\% of patients receiving placebo }(P=0.005)\end{array}$ \\
\hline \multicolumn{6}{|c|}{ Burn and wound care } \\
\hline $\begin{array}{l}\text { Wasiak et al } \\
(20 \mid 4)^{51}\end{array}$ & 3 & $\begin{array}{l}\text { Prospective single- } \\
\text { center case series }\end{array}$ & (I5) & NR & $\begin{array}{l}\text { - Median (IQR) NRS pain scores were significantly } \\
\text { higher postdressing than predressing: predressing } \\
2(I-3) \text { vs postdressing } 3(I .5-4) ; P=0.0 \text { I } \\
\text { - Median (IQR) NRS anxiety scores reduced } \\
\text { significantly following wound dressing: predressing } \\
5(4-7) \text { vs postdressing } 2(I-2) ; P<0.00 I\end{array}$ \\
\hline
\end{tabular}

(Continued) 
Table 4 (Continued)

\begin{tabular}{|c|c|c|c|c|c|}
\hline Reference & $\begin{array}{l}\text { Evidence } \\
\text { level }\end{array}$ & Design & $\begin{array}{l}\text { Number of } \\
\text { patients } \\
\text { (received } \\
\text { analgesic } \\
\text { methoxyflurane) }\end{array}$ & $\begin{array}{l}\text { Age } \\
\text { restriction } \\
\left(\text { (years) }^{a}\right.\end{array}$ & Efficacy results \\
\hline $\begin{array}{l}\text { Gaskell et al } \\
(2016)^{44}\end{array}$ & 3 & $\begin{array}{l}\text { Joint publications } \\
\text { including crossover } \\
\text { comparator and case } \\
\text { series } \\
\text { Single center, } \\
\text { randomized, } \\
\text { crossover study vs } \\
\text { ketamine-midazolam } \\
\text { PCA } \\
\text { Joint publications } \\
\text { including crossover } \\
\text { comparator and case } \\
\text { series } \\
\text { Case series }\end{array}$ & (123) & (1) & $\begin{array}{l}\text { - Five patients expressed a preference for } \\
\text { methoxyflurane over ketamine-midazolam PCA } \\
\text { - Methoxyflurane successfully facilitated analgesia in } \\
\text { all } 9 \text { I dressing changes carried out in } 41 \text { patients } \\
82 \text { patients underwent minor surgical and } \\
\text { radiological procedures: methoxyflurane provided } \\
\text { adequate analgesia in } 77 \text { ( } 94 \% \text { ) of these }\end{array}$ \\
\hline \multicolumn{6}{|c|}{ Nasoduodenal intubation } \\
\hline $\begin{array}{l}\text { Moss et al } \\
(2011)^{48}\end{array}$ & I & $\begin{array}{l}\text { Randomized, double- } \\
\text { blind, placebo- } \\
\text { controlled study }\end{array}$ & $60(30)$ & NR & $\begin{array}{l}\text { - Patient comfort during nasoduodenal intubation } \\
\text { was better with methoxyflurane }(5.0,95 \% \mathrm{Cl} \\
4.0,6.0) \text { than with placebo }(2.7,95 \% \mathrm{Cl} \mathrm{I.8,3.7} \text {; } \\
P=0.002) \\
\text { - No significant differences for comfort levels } \\
\text { overall ( } 4.8 \text { vs } 4.0, P=n s)\end{array}$ \\
\hline \multicolumn{6}{|c|}{ Bridging analgesia in labor } \\
\hline $\begin{array}{l}\text { Anwari et al } \\
(2015)^{52}\end{array}$ & 5 & $\begin{array}{l}\text { Prospective } \\
\text { observational study }\end{array}$ & (64) & NR & $\begin{array}{l}\text { - Mean baseline NRS pain score reduced from } \\
8.2 \pm I .5 \text { to } 6.2 \pm 2 \text { after first inhalation }(P<0.000 \mathrm{I}) \text {, } \\
4.8 \pm 2.0 \text { after the second inhalation }(P<0.000 \mathrm{I}) \text {, } \\
\text { and } 3.4 \pm \mathrm{I} .5 \text { after the third inhalation }(P<0.000 \mathrm{I}) \\
\text { Richmond Agitation Sedation Scale improved after } \\
\text { each inhalation cycle }(P<0.000 \mathrm{I})\end{array}$ \\
\hline
\end{tabular}

Notes: Evidence level: Level I=evidence from meta-analysis or randomized clinical trials, Level 2=evidence from individual studies, Level $3=e v i d e n c e$ from quasi-experimental studies, Level 4=evidence from descriptive studies, Level $5=$ evidence from case reports, Level $6=$ specialist opinion. ${ }^{a}$ As stipulated in inclusion criteria.

Abbreviations: AADS, anesthesia-assisted deep sedation; IQR, interquartile range; NR, not reported; NRS, numeric rating scale; PCA, patient-controlled analgesia; PILA, peri-prostatic infiltration of local analgesia; VAS, visual analog scale; VRS, verbal rating scale.

exposure doses than those seen with the current inhaler configuration. ${ }^{2}$ There is a present-day need to understand the clinical evidence supporting the current formulation of inhaled analgesic methoxyflurane in trauma pain. Much of the evidence is real-world observational data derived mainly from the pre-hospital and ED setting. ${ }^{25-37}$

In Europe, methoxyflurane is approved for use as an inhaled analgesic in conscious adults who have moderate to severe pain associated with trauma. ${ }^{16}$ This license was granted based on clinical evidence from STOP! - a randomized controlled trial (RCT) in patients with acute trauma pain, carried out in the $\mathrm{UK},{ }^{25}$ in which eligible patients aged $\geq 12$ years with pain scores between 4 and 7 on the 11 -point numerical rating scale (NRS), were randomized on presentation to the ED in a 1:1 ratio to methoxyflurane $(n=149)$ or placebo $(n=149)$, with a total of 90 adolescent patients (aged
12-17 years) included in the study. Change in pain intensity from baseline (primary endpoint) was measured using a 100 mm visual analog scale (VAS) at 5, 10, 15, and 20 minutes after administration of the study drug; mean baseline VAS score was $\sim 64 \mathrm{~mm}$. The trial showed that methoxyflurane resulted in a significantly greater reduction in pain score than placebo overall across all time points $(-30.2 \mathrm{vs}-15.2 \mathrm{~mm}$; estimated treatment effect: $-15.1 \mathrm{~mm}$; 95\% CI: $-19.2,-11.0$; $P<0.0001$ ), and rescue medication use was significantly lower after methoxyflurane than placebo (Table 2). Over $80 \%$ of patients receiving methoxyflurane experienced initial pain relief within 10 inhalations, compared with approximately half of those receiving placebo, and the median time to first pain relief was 4 minutes with methoxyflurane and 10 minutes with placebo. When adult-only data from this study were evaluated, efficacy results were broadly comparable to the 
overall cohort, with an overall treatment effect for the primary endpoint of $-17.4 \mathrm{~mm}(95 \% \mathrm{CI}:-22.3,-12.5 ; P<0.0001) .{ }^{18}$ The median time between dispensing the first and second inhalers, in those patients requesting a second inhaler, was 54 minutes (range 30-120 minutes). ${ }^{18}$ A difference of 13-14 $\mathrm{mm}$ on the $100 \mathrm{~mm}$ VAS has been hypothesized to represent the minimum clinically important difference in acute pain for adult trauma patients; ${ }^{38-40}$ the treatment difference for the change from baseline in VAS pain intensity exceeded this in both the overall study population and the adult cohort of the STOP! study, despite the considerable "placebo effect." 18,25

The placebo effect observed in the STOP! study (a change of $15 \mathrm{~mm}$ on the $100 \mathrm{~mm} \mathrm{VAS}$, equivalent to $\sim 1.5$ on the $\mathrm{NRS}^{38}$ ) is not unexpected in pain research ${ }^{41}$ and is similar to the degree of pain relief with IM tramadol seen in a recent prospective, randomized head-to-head study in the prehospital setting (median reduction in pain score of 1.0 at 5 and 10 minutes, compared with 3.0 and 2.0, respectively, for methoxyflurane). ${ }^{31}$ Median time to effective analgesia for methoxyflurane was comparable to the STOP! study at 3 minutes and was 5 minutes for IM tramadol. ${ }^{31}$ Konkayev et al reported a reduction in pain score from 4.1 to 0.6 with methoxyflurane and from 5.5 to 4.2 with IM tramadol at 5 minutes in another prospective study in the ED. ${ }^{29}$ Observational case series of analgesic methoxyflurane have also shown reductions in verbal NRS (VNRS) pain scores of 2.47 at 5 minutes and 3.21 on arrival at the $\mathrm{ED}^{26}$ and 2.3 and 3.3 at 15 and 30 minutes, respectively. ${ }^{28}$

A large retrospective comparative study of 52,046 adult patients in Australia with moderate to severe pain (mean initial VNRS pain score of 8.4) treated with intravenous (IV) morphine, IN fentanyl, or inhaled methoxyflurane by paramedics showed that all three analgesic agents provided effective analgesia in the majority of patients $(81.8 \%, 80.0 \%$, and $59.1 \%$, respectively, achieving a reduction in pain severity of $\geq 30 \%$ on the VNRS), but morphine and fentanyl were significantly more effective than methoxyflurane $(P<0.0001) .{ }^{27}$ The mean reduction in VNRS score with methoxyflurane (3.2) was similar to that observed in other studies discussed above, ${ }^{26,28,29,31}$ but lower than that for IV morphine and IN fentanyl (both 4.5). ${ }^{27}$ In contrast, a retrospective study of methoxyflurane vs IN fentanyl including 13,963 patients by Oxer et al showed that both the agents provided good or partial pain relief in over $90 \%$ of patients. ${ }^{30}$

Nitrous oxide is another self-administered, rapid-acting, nonnarcotic, and noninvasive inhalational analgesic agent used in the ED. Although no head-to-head trials have been performed, an indirect comparison of methoxyflurane and nitrous oxide for trauma pain in a recent review revealed no significant difference between the two agents for change in pain intensity at 5,10 , or 15 minutes after the start of inhalation, although data were in favor of methoxyflurane. ${ }^{42}$

Across the studies, patients, paramedics, and nurses expressed satisfaction with the pain control provided by methoxyflurane (Table 2). ${ }^{25,26,30}$ In the STOP! study, methoxyflurane's global medication performance was rated as excellent, very good, or good in over $80 \%$ of cases. ${ }^{25}$ Buntine et al reported that $72 \%$ of patients and $82 \%$ of paramedics were satisfied with the level of analgesia provided by methoxyflurane in the prehospital setting in an observational cases series. ${ }^{26}$

\section{Inhaled analgesic methoxyflurane in pediatric trauma pain}

While not currently approved in Europe for use in the pediatric setting, methoxyflurane is approved for use in children in Australia and New Zealand. ${ }^{14,15}$ It is useful to understand the clinical utility of analgesic methoxyflurane in this setting and how it might differ from use in adults. A number of studies including children have been carried out in both the prehospital and ED settings (Table 3). ${ }^{32-35}$ An observational case series study of prehospital analgesia in 105 children (mainly with extremity injuries) receiving methoxyflurane showed a mean 4.7-point reduction in VNRS pain scores (as assessed by paramedics) after 10 minutes, with $88.5 \%$ of paramedics, $91.3 \%$ of parents and $87.0 \%$ of patients being satisfied to very satisfied with treatment and $96.9 \%$ of parents/older patients stating that they would be willing to use methoxyflurane again for pain control ${ }^{33}$ In a pilot observational case series study of methoxyflurane analgesia for brief painful procedures or bridging analgesia for extremity trauma in the $\mathrm{ED}$, pediatric patients reported a rapid onset of action (anecdotally within 30 seconds) with 13/14 patients willing to receive methoxyflurane again for the same indication. ${ }^{32}$ In this study, four patients with fractures with high initial pain scores $(\geq 6)$ who received methoxyflurane as bridging analgesia experienced drops in pain scores of between 2 and 7 points, whereas six patients who had painful procedures undertaken reported intraprocedural pain scores ranging from 0 to 3; physician/nurse/parent/patient were satisfied or very satisfied with methoxyflurane analgesia in these cases. ${ }^{32}$ However, four patients with lower initial pain scores of 2-3.5 did not experience satisfactory procedural analgesia during fracture reduction or patella relocation. ${ }^{32}$

A pilot RCT in 41 children with upper limb fracture reported a 2.7-point greater reduction in pain (0-10 point scale) at 10 minutes with methoxyflurane compared with 
placebo $(P<0.05) .{ }^{35}$ Similar to the findings of Middleton et al in adult patients, ${ }^{27}$ a retrospective comparative study of 3,312 pediatric patients with moderate to severe pain (pain score $\geq 5$ ) in the out-of-hospital setting showed that IV morphine and IN fentanyl are associated with significantly greater odds of effective analgesia than methoxyflurane. ${ }^{34}$ Nevertheless, $78.3 \%$ of those receiving methoxyflurane as a sole agent achieved effective analgesia (defined as a decrease in pain intensity of $\geq 30 \%$ on the VNRS), compared with $87.5 \%$ for IV morphine and $89.5 \%$ for IN fentanyl. ${ }^{34}$ Combination analgesia was not found to be better than either fentanyl or morphine alone. Scene time and transport time were significantly longer for patients given morphine, fentanyl, or analgesic combinations than for patients given methoxyflurane. ${ }^{34}$

Three additional studies included both adult and pediatric patients (Table 2). The STOP! study found no significant difference in treatment effect between adolescents and adults, ${ }^{25}$ while Gillis et al reported a mean reduction in VNRS scores of 2.3 and 3.3 at 15 and 30 minutes in a mixed population of 59 adult and pediatric patients aged $>3$ years. ${ }^{28} \mathrm{~A}$ retrospective analysis of prehospital use by Oxer et al found that $67.8 \%$ of patients aged $<12$ years and $54.5 \%$ of patients aged $>12$ years rated pain relief with methoxyflurane as good/excellent, compared with $52.9 \%$ overall for IN fentanyl. ${ }^{30}$

\section{Inhaled analgesic methoxyflurane in procedural pain}

Methoxyflurane is widely used in Australia and New Zealand for analgesia during medical procedures, and published studies of methoxyflurane in procedural analgesia are summarized in Table 4 and briefly discussed below. ${ }^{43-52}$ A more detailed review of methoxyflurane as an analgesic for outpatient procedures has recently been published. ${ }^{53}$

In a prospective, randomized colonoscopy study, patients receiving methoxyflurane experienced comparable pain relief and procedural success rate to those receiving conventional sedation with IV midazolam and fentanyl, with the benefit of faster recovery and discharge, although additional IV sedation was required for 10 of 125 patients $(8 \%)$ who received methoxyflurane. ${ }^{49} \mathrm{~A}$ further colonoscopy study in patients with morbid obesity and/or obstructive sleep apnea showed that methoxyflurane was associated with a shorter total procedural time ( 24 vs 52 minutes, $P<0.001$ ), a lower incidence of hypotension ( $3 / 85$ vs $23 / 55$ patients, $P<0.001)$ and respiratory desaturation ( $0 / 85$ vs $14 / 55$ patients, $P<0.001)$ as well as quicker recovery and time to discharge (27 vs 97 minutes, $P<0.0001)$ than conventional IV sedation. ${ }^{50}$ In the latter study, no methoxyflurane-treated patients required IV sedation, $90 \%$ were willing to receive methoxyflurane again for colonoscopy and of patients who had received conventional sedation for previous colonoscopies, $82 \%$ preferred to receive methoxyflurane for future colonoscopies. ${ }^{50}$

Two single-arm studies of methoxyflurane analgesia in patients undergoing prostate biopsy showed that median pain scores were $\leq 3$ (on a $0-10$ scale) both during and immediately after the procedure. ${ }^{45,47}$ In one of these studies, all 42 patients stated that they would be happy to undergo the same procedure again if clinically indicated. ${ }^{45}$ In the second study, median pain scores during prostate biopsy with methoxyflurane were found to be significantly higher than those during previous biopsy using peri-prostatic infiltration of local analgesia (PILA) in the 11 patients who had pain scores for both procedures (4.0 vs 2.0, $P=0.012$ ); however, it should be noted that the PILA procedure itself is painful and does not address pain that is associated with ultrasound probe insertion. ${ }^{47}$ The combination of both methoxyflurane and PILA has shown promise in prostate biopsy, resulting in significantly lower pain scores than methoxyflurane alone (median pain score 2 vs $3, P=0.014)$; despite this difference in pain scores, all patients in both the treatment groups stated that they would be happy to have another prostate biopsy in future. ${ }^{46}$

Cancer patients undergoing bone marrow biopsy reported significantly lower mean NRS pain scores with methoxyflurane than placebo (each co-administered with local anesthesia) for "worst pain overall" ( 4.9 vs $6.0, P=0.011)$ and "worst pain during aspiration" (3.3 vs 5.0, $P<0.001)$ in a randomized, double-blind study by Spruyt et al. ${ }^{43}$ Forty-nine percent of patients treated with methoxyflurane rated the medication as very good or excellent compared with $16.5 \%$ of the patients treated with placebo $(P=0.005) .{ }^{43}$ In a randomized, doubleblind study of patients undergoing computed tomographic enteroclysis (small bowel enema), patient comfort scores measured on a $10 \mathrm{~cm}$ VAS were significantly higher with methoxyflurane compared with placebo for the nasoduodenal intubation part of the procedure (5.0 vs $2.7, P=0.002) .{ }^{48}$ Women receiving methoxyflurane as a bridging analgesic prior to epidural placement during labor reported significantly decreased mean NRS pain scores from baseline (8.2 \pm 1.5$)$ to the first, second, and third contractions after commencement of methoxyflurane inhalation $(6.2 \pm 2.0,4.8 \pm 2.0$, and $3.7 \pm 1.5$, respectively, $P<0.0001$ at all time points), as well as high satisfaction with methoxyflurane treatment. ${ }^{52}$

Burn care procedures such as dressing changes, tissue debridement, and skin grafting can be particularly painful and may cause considerable anxiety, especially if pain has not previously been managed adequately during these procedures. 
In a small case series of patients in an ambulatory burn care setting, median NRS pain scores were predictably higher after dressing changes than before ( 3 vs $2, P=0.01$ ), despite the use of methoxyflurane; however, anxiety scores were significantly lower ( 5 vs $2, P<0.001) .{ }^{51}$ In a small pilot crossover study of patients undergoing burns dressing procedures by Gaskell et al, five of eight patients preferred methoxyflurane to ketamine-midazolam patient-controlled analgesia (PCA), whereas one preferred ketamine-midazolam PCA and two expressed no preference. ${ }^{44}$ Reasons given for preference for methoxyflurane included easier administration, feeling more in control, absence of hallucinations, greater ability to cooperate, and better recovery. The same authors reported that in a case series of 41 patients undergoing a total of 91 dressing changes, methoxyflurane successfully facilitated analgesia in all cases. ${ }^{44}$

Overall, methoxyflurane provides good procedural analgesia with the ease and control of self-administration by the patient. This contrasts with the administration of IV sedation and narcotic analgesia, which requires greater staff involvement for administration and monitoring and longer time to discharge, although this must be balanced against the likely greater degree of pain relief provided for very painful procedures such as bone marrow biopsy. Nevertheless, satisfaction with methoxyflurane was reported as high among patients undergoing medical procedures in the studies summarized, with many stating that they would be happy to undergo the procedure again if methoxyflurane were used (Table 4). ${ }^{45,47,50}$

\section{Safety of methoxyflurane as a low- dose inhalational analgesic}

The historical perspective for methoxyflurane and its link to nephrotoxicity in the anesthetic setting requires that the tolerability and safety of the current inhaled formulation is explored. It is essential that we understand the adverse event (AE) and toxicity profile of inhaled analgesic methoxyflurane, for example, nephrotoxicity, to be confident in its clinical use.

\section{Nephrotoxicity}

Recommended analgesic doses of methoxyflurane have not been associated with nephrotoxicity, and no cases due to low-dose use of methoxyflurane have been reported in the literature, ${ }^{54,55}$ although a single case of renal failure potentially related to methoxyflurane use has been reported to Australia's Database of Adverse Event Notifications between 1975 and February 2018. ${ }^{56}$

Exposure to inhaled anesthetics is measured as the minimum alveolar concentration (MAC; the minimum concentration required to produce surgical anesthesia in $50 \%$ of healthy patients), and overall exposure is measured as MAChours. The safe upper limit of exposure to methoxyflurane is 2 MAC-hours, which gives a serum fluoride level of 40 $\mu \mathrm{mol} / \mathrm{L}$, below which no toxicity has been demonstrated (Table 5). ${ }^{54}$ The maximum exposure to methoxyflurane from a single methoxyflurane device is 0.3 MAC-hours, while the maximum recommended dose for analgesia of five inhalers a week ( $15 \mathrm{~mL}$ methoxyflurane; not to be used on consecutive days $^{16,54}$ ) provides a maximum of 0.59 MAC-hours, which gives a safety margin for analgesic use of 2.7- to 8-fold. A limited increase in serum fluoride levels after analgesic use of methoxyflurane has been observed in a study of patients undergoing bone marrow biopsy compared with placebo, but serum fluoride levels were below known toxic levels and no clinical or biochemical sequelae were observed. ${ }^{43}$

\section{Tolerability}

Reports of AEs with analgesic methoxyflurane overall in clinical practice are rare; despite widespread use in Australia, 14 $\mathrm{AE}$ reports have been submitted to the Australian regulatory authorities in total over the 43 years since methoxyflurane became available as a $3 \mathrm{~mL}$ dose for analgesic use. ${ }^{56}$ In 10

Table 5 Overview of nephrotoxicity and serum fluoride levels

\begin{tabular}{|l|l|l|l|}
\hline & MAC hours & $\begin{array}{l}\text { Serum fluoride } \\
\text { levels ( } \boldsymbol{\mu m o l} / \mathbf{L})\end{array}$ & $\begin{array}{l}\text { Blood methoxyflurane } \\
(\mathbf{m g} / \mathbf{m L})\end{array}$ \\
\hline Analgesic dosing of methoxyflurane & & & \\
\hline Penthrox 3 mL & 0.3 & $4.7^{\mathrm{b}}$ & $0.006-0.026^{\mathrm{a}}$ \\
\hline Anesthetic dosing of methoxyflurane & & & \\
\hline Calculated average & 1.0 & 20 & $10-13$ \\
Safe upper limit & 2.0 & 40 & $20-26$ \\
Subclinical toxicity & $2.5-3.0$ & $>50$ & $25-33$ \\
Clinical toxicity & $>5$ & $>90$ & $>45$ \\
\hline
\end{tabular}

Notes: Data from Dayan. ${ }^{54}$ aBased on data of $0.6-2.6 \mathrm{mg} / 100 \mathrm{~mL}$ blood. ${ }^{b}$ Derived from analysis of mean serum fluoride levels in patients undergoing bone marrow biopsy. 
of these AE reports, methoxyflurane was the only suspected medicine. ${ }^{56}$ Published studies confirm that methoxyflurane is well tolerated in both adults ${ }^{18,25,26,43,45,46,48}$ and children..$^{32,33}$ No treatment-related serious AEs or cases of oxygen saturation $<90 \%$ have been reported. The most common AEs are central nervous system-type reactions, such as dizziness and somnolence; ${ }^{16}$ generally AEs are mild and transient, resolving after inhalation is stopped. ${ }^{16}$ Anecdotally, patients comment that analgesic methoxyflurane has a distinctive fruity smell, which some find unpleasant.

In the STOP! study, 88 patients $(59.1 \%)$ treated with methoxyflurane experienced treatment-emergent adverse effects (TEAEs), compared with 61 (40.9\%) who received placebo; the most common TEAEs were headache and dizziness. ${ }^{25}$ Two patients treated with methoxyflurane and three who received placebo withdrew from the study because of TEAEs; in all cases, the TEAE resolved later the same day. ${ }^{25}$ In an observational case series of prehospital methoxyflurane analgesia in 83 adult patients by Buntine et al, 15 patients (18.1\%) reported mild side effects including nausea (seven patients), euphoria (three patients), dizziness (two patients), headache, hallucinations, sore throat, and lip paresthesia. ${ }^{26}$

Among pediatric patients, an observational case series of methoxyflurane in the prehospital setting in 105 pediatric patients reported 38 patients $(36.2 \%)$ with AEs, most commonly drowsiness $(25.7 \%)$ and hallucinations/disinhibition $(6.7 \%){ }^{33}$ Five of 15 patients aged $<5$ years experienced deep sedation. ${ }^{33}$ In a prospective observational case series of 14 children requiring procedural analgesia in the ED, five patients had six brief self-resolving AEs including cough (two patients), agitation, euphoria, blurry vision, and dizziness. ${ }^{32}$

The tolerability profile of methoxyflurane is similar when used as procedural analgesia. Among patients undergoing nasoduodenal intubation, $6 / 30(20 \%)$ receiving methoxyflurane and $2 / 30(7 \%)$ receiving placebo experienced mild AEs; in the methoxyflurane group, these were vomiting (three patients), nausea, cough, and mild wheeze. ${ }^{48}$ Similarly, 10/49 patients (20.4\%) receiving methoxyflurane and $2 / 48$ patients $(4.2 \%)$ receiving placebo during bone marrow biopsy experienced AEs; most common in the methoxyflurane group were dizziness (four patients) and euphoria (two patients). ${ }^{43}$ Gaskell et al reported AEs of hypotension, cough, vomiting, nausea, agitation, headache, over sedation (sedation score $>2$ ), and oxygen saturation $\left(\mathrm{SpO}_{2}<93 \%\right)$ each in between one and three patients of 123 undergoing 173 episodes of inhaled methoxyflurane analgesia. ${ }^{44}$ Patients receiving methoxyflurane analgesia during prostate biopsy have reported brief lightheadedness, ${ }^{45}$ coughing and lowered Glasgow Coma Scale, ${ }^{46}$ and a sickly sweet taste. ${ }^{45,46}$

\section{Safety}

With over 40 years of clinical use as an analgesic in Australia, methoxyflurane has an established safety profile. Methoxyflurane has no observed clinically significant effect on systolic blood pressure, pulse rate, respiratory rate, or consciousness levels, ${ }^{57,58}$ and there have been no reports of nephro- or hepatotoxicity in clinical studies of analgesic methoxyflurane. ${ }^{25,54,55}$ An isolated case of acute hepatitis was observed in a patient who received repeated weekly exposure to methoxyflurane during several varicose vein sclerosing procedures; its use was continued despite the appearance of possible hepatotoxicity after the second treatment; however, this patient's disorder resolved within 4 weeks. ${ }^{59}$ A single case reported to the Australian regulatory authorities showed evidence of nephrotoxicity secondary to hepatic failure rather than being directly attributable to methoxyflurane. ${ }^{56} \mathrm{~A}$ large data-linkage study conducted in 135,770 patients in the prehospital setting in Australia over 10 years (including 17,628 who received methoxyflurane, most commonly for trauma) evaluated the incidence rates of a range of conditions, including heart disease, renal disease, hepatic disease, diabetes, and cancer. ${ }^{55}$ Over the course of the study, there were no differences in event rates for heart disease, renal disease, hepatic disease, diabetes, or cancer, between patients who received methoxyflurane and those who did not. ${ }^{55}$

\section{Occupational exposure}

To date, there has been no evidence of adverse effects among paramedical or medical staff associated with the use of low analgesic doses of methoxyflurane. Frangos et al recently derived a maximum 8-hour safe occupational exposure limit for methoxyflurane of $15 \mathrm{ppm} .{ }^{60}$ This is up to 65 times higher than the 8-hour exposure levels measured within the confines of ambulances $(n=45)$ of 0.23 ppm when no AC chamber was used. ${ }^{60}$ Even under modeled conditions for treatment rooms and ambulances, a modeled exposure of $1.5 \mathrm{ppm}$ is 10 -fold lower than the established safety threshold..$^{60}$ In both cases, use of low-dose methoxyflurane was assumed or observed, without its $\mathrm{AC}$ chamber, ${ }^{60}$ which adsorbs methoxyflurane to reduce occupational exposure by $>80 \%$ and is mandatory for use across Europe. A recent study by Ruff et al also found that methoxyflurane exposure levels in staff breathing zones were well below the safety threshold of 15 ppm (median 8-hour exposure level: $0.38 \mathrm{ppm}$; range: $0.05-2.88 \mathrm{ppm}$ ) where analgesic methoxyflurane administered by an inhaler fitter with an AC filter was used for procedural sedation during bone marrow biopsy lists. ${ }^{61}$ 


\section{Abuse potential}

Data on historic use of higher-dose anesthetic methoxyflurane reported a small number of cases of methoxyflurane abuse, ${ }^{62-67}$ however, there is no evidence that methoxyflurane increases the activity of the reward pathway by increasing dopamine transmission. There have been no published reports of abuse related to the analgesic methoxyflurane device, which is restricted to administration under the supervision of a suitably trained and qualified personnel, and packaged to minimize abuse potential.

\section{The place of inhaled analgesic methoxyflurane in the therapy of traumatic pain} Unmet needs in trauma pain management Despite national clinical guidelines on the management of acute traumatic pain stressing the importance of making pain management available to all patients, ${ }^{68,69}$ acute pain is often poorly managed in both the prehospital and ED settings. ${ }^{70,71}$ Reasons for this include failure to assess pain (either accurately or, in some cases, at all) at the scene of an accident, or on arrival in the ED; failure of ambulances to carry appropriate analgesics; lack of time and resources on the part of triage nurses; and reluctance to administer opioids on the part of ambulance staff or paramedics. ${ }^{72-76}$

The limitations of available analgesic options may also be a contributing factor to failures in the management of traumatic pain. Current analgesics present several limitations in the treatment of pain in trauma with respect to their routes of administration, strength of analgesia, side effect profiles, and pharmacokinetic properties. ${ }^{77}$ For opioids, access is often restricted, and they require physiological monitoring during use, making them difficult to prescribe, and time-consuming to administer. Concerns over AEs, dependence and abuse, the requirement for training in IV opioid administration, and a general reluctance on the part of healthcare providers to prescribe opioids are all additional barriers to effective, immediate pain management. However, IN fentanyl is a widely accepted emergency pain relief strategy that offers a convenient dose form with fast onset of action and effective analgesia, ${ }^{78,79}$ although only limited quality evidence exists for its efficacy in this setting, ${ }^{80,81}$ and patients may experience similar side effects to IV opioid analgesia. ${ }^{82}$ IN ketamine at subdissociative doses may provide non-opioid analgesia comparable with that reported for IN fentanyl, ${ }^{83-85}$ with less severe AEs (commonly transient dizziness and poor taste), and further studies investigating the effectiveness of IN fentanyl and IN ketamine are ongoing. ${ }^{86,87}$
The use of oral nonsteroidal anti-inflammatory drugs (NSAIDs) and acetaminophen for traumatic pain can reduce opioid requirements; however, onset of action is slow. NSAIDs are also associated with a number of gastrointestinal AEs, ${ }^{88}$ and in some countries are not recommended for prehospital use in the emergency care setting ${ }^{89}$ Nitrous oxide is fast acting, providing a significant reduction in pain intensity within 5 minutes, but it can be difficult to use at low temperatures, ${ }^{90,91}$ and its canisters are bulky and heavy, making them unwieldy to transport and maneuver in situations where access to a patient is physically limited. ${ }^{92}$ In addition, many patients do not have the inspiratory capacity to trigger the demand valve for successful inhalation of nitrous oxide, a particular problem in elderly patients. ${ }^{42}$ It must also be used with caution in patients with chest injury, owing to the risk of accumulation of gas and rapid worsening of a pneumothorax if present. ${ }^{90}$

As a result, there remains an unmet need for analgesia in the prehospital and ED settings that is effective, simpleto-use, and easily portable, with both a rapid onset of action and a favorable safety profile.

\section{Benefits of inhaled analgesic methoxyflurane in the management of trauma pain}

Inhaled analgesic methoxyflurane has a number of features that make it an attractive option as a prehospital and ED analgesic. The onset of pain relief is fast; important to minimize the delay before the patient can be transported to hospital, or when administered during the journey itself. Methoxyflurane analgesia occurs within 4-5 minutes, ${ }^{16,25}$ comparable to the onset of both IV morphine ${ }^{93}$ and nitrous oxide, ${ }^{94}$ and more rapidly than the onset of IN or oromucosal fentanyl. ${ }^{95}$ Indeed, the overall total time to onset of pain relief is theoretically shorter with methoxyflurane than with IV morphine, which requires the patient to be cannulated and various procedures surrounding the administration of controlled drugs to be followed. In a retrospective analysis of $>50,000$ adults, care time was shorter for methoxyflurane-treated patients (28 minutes) than IN fentanyl (34 minutes) or IV morphine (37 minutes). ${ }^{27}$ Similarly, in an analysis of $>3,000$ pediatric patients, on-scene time was significantly shorter for patients treated with methoxyflurane than for those treated with IV morphine or IN fentanyl (14 vs 21 or 18 minutes; $P<0.0001$ ). ${ }^{34}$ However, it should also be considered that these studies found that methoxyflurane was significantly less effective than IN fentanyl and IV morphine (although still providing effective analgesia in $59.1 \%$ of adult patients ${ }^{27}$ and $78.3 \%$ of pediatric patients), ${ }^{34}$ and this needs to be balanced against the ability 
to administer methoxyflurane analgesia simply, quickly, and effectively without the need for prescription. In addition to the rapid provision of pain relief, methoxyflurane may be used across a wide temperature range $\left(-20^{\circ} \mathrm{C}\right.$ to $\left.40^{\circ} \mathrm{C}\right)$, making it ideal for use in austere circumstances. Finally, methoxyflurane may be administered in ambulatory patients with pain, compared with IV opiates which mandate the patient being in bed, for reasons of risk and safety, and patients can control their own level of analgesia while waiting for further treatment.

Inhaled analgesic methoxyflurane does not cause respiratory depression and has no effect on vital signs. ${ }^{57,58}$ Its effects are rapidly reversed once inhalation stops (within 3-20 minutes), allowing time for additional analgesia to be given or for further medical assessments to be made, and there are no reported drug interactions when used at the analgesic dosage. ${ }^{16}$ Recent data in healthy volunteers suggest that patients can drive and operate machinery on the day of use, ${ }^{96}$ an attribute that may be of potential use in medical procedures as opposed to the current use of conscious sedation.

\section{Potential cost advantages for inhaled analgesic methoxyflurane}

Although no formal cost analysis exists for methoxyflurane in traumatic pain, data suggest that early administration of effective analgesia has benefit for time spent in the ED and levels of overcrowding. ${ }^{97}$ In colonoscopy, a cost comparison of analgesic methoxyflurane vs anesthesia-assisted deep sedation (AADS) indicated that costs were halved (AUS\$331.79 vs AUS\$725.41)..$^{50}$ In addition, procedure times were shorter, enabling more procedures to be performed in a 4-hour clinic with methoxyflurane than AADS (8 vs 4$).^{50}$

\section{Directions for future research}

A clear limitation of the available data on low-dose methoxyflurane analgesia is the sparsity of comparative data from large RCTs. Although the STOP! study was a large RCT, it was placebo-controlled rather than active controlled, and results were confounded to some extent by a large placebo effect and availability of rescue medication at the patient's request (a necessity for ethical reasons). ${ }^{25}$ Other RCTs have compared methoxyflurane with IM tramadol, a weak analgesic $^{98}$ rarely used in the prehospital or ED setting. This lack of high quality, clinically relevant comparative data is currently being addressed by a number of ongoing or recently completed studies. A large Phase IIIb open RCT comparing methoxyflurane and emergency analgesic standard of care treatment for treating adult patients with trauma pain in Spanish emergency units (including ambulances, emergency primary care, and ED settings), with coprimary endpoints of change from randomization in NRS pain intensity over the first 20 minutes of treatment and time to first pain relief, has recently been completed. ${ }^{99,100} \mathrm{~A}$ similar ongoing RCT in Italy is investigating the efficacy and safety of methoxyflurane analgesia compared with IV morphine (for severe pain [NRS 27]) or IV paracetamol (for moderate pain [NRS 4-6]) in the treatment of acute trauma pain. ${ }^{101}$

Although patients aged 12-18 years were included in the STOP! study, ${ }^{25}$ no data are currently available from a large $\mathrm{RCT}$ in pediatric patients. A placebo-controlled trial investigating methoxyflurane for acute, trauma-related pain in 220 children aged 6-18 years is ongoing in the UK, which will provide further insight into efficacy and safety in this patient group. ${ }^{102}$ Results from these trials should help further inform physicians and guidelines regarding the appropriate use of methoxyflurane analgesia in the prehospital and ED settings.

\section{Conclusion}

Methoxyflurane is an inhaled, self-administered, fast-acting analgesic which has been available for over 40 years in Australia, for both the management of pain associated with trauma and for medical procedures in children and adults. It has recently been approved in several other countries, with further approvals ongoing, and is licensed in Europe for use in adult patients with trauma-associated pain. A broad range of data for inhaled analgesic methoxyflurane exist although in acute trauma pain, much of this is observational or retrospective. However, a small number of RCTs do exist, one of which, STOP!, has formed the basis for approval in trauma pain in Europe. In procedural pain, inhaled analgesic methoxyflurane has been used across a wide range of procedures, with most data collected in burns and wound dressing changes, prostate biopsy and colonoscopy. Published data on methoxyflurane in traumatic and procedural pain show it to be effective, well-tolerated, and highly rated by patients.

With its rapid onset of effective pain relief, easy-touse and portable inhaler, and nonopioid nature, inhaled methoxyflurane is an option for patients in the emergency setting, be that prehospital or the ED. Methoxyflurane may be particularly relevant in patients, able to self-administer analgesia without the need for needles but where analgesia is required to facilitate ongoing treatment or as a bridge to other analgesic options with a slower onset. With a wellestablished safety profile, and no apparent nephrotoxicity at analgesic doses, methoxyflurane is an attractive option for pain management in prehospital and ED settings, and further robust study data are awaited. 


\section{Acknowledgments}

Under the direction of the authors, Dr Jennifer Green and Dr Susan Allen (BrandFish Limited) provided technical and editing services for the initial versions of the manuscript and Karen Mower (Scientific Editorial) provided editorial assistance in the later versions of the manuscript, both funded by Mundipharma International Limited. Penthrox ${ }^{\circledR}$ is a registered trademark of Medical Developments International Limited.

\section{Author contributions}

All authors developed the scope and search criteria for this review and critically reviewed all drafts of the manuscript, edited, and approved the final version for submission.

\section{Disclosure}

KMP, ADD, and PMM have previously served as speakers, consultants, and advisory board members for Mundipharma International Limited and Medical Developments International. SD is an employee of Mundipharma International Limited. The authors report no other conflicts of interest in this work.

\section{References}

1. Tomlin PJ. Methoxyflurane. Br J Anaesth. 1965;37(9):706-709.

2. Stephen CR. Clinical applications of methoxyflurane. Acta Anaesthesiol Scand Suppl. 1966;24:215-222.

3. Mazze RI. Methoxyflurane revisited: tale of an anesthetic from cradle to grave. Anesthesiology. 2006;105(4):843-846.

4. Tomi K, Mashimo T, Tashiro C, et al. Alterations in pain threshold and psychomotor response associated with subanaesthetic concentrations of inhalation anaesthetics in humans. Br J Anaesth. 1993;70(6):684-686.

5. Crandell WB, Pappas SG, Macdonald A. Nephrotoxicity associated with methoxyflurane anesthesia. Anesthesiology. 1966;27(5): 591-607.

6. Cousins MJ, Mazze RI. Methoxyflurane nephrotoxicity. A study of dose response in man. JAMA. 1973;225(13):1611-1616.

7. Kharasch ED, Schroeder JL, Liggitt HD, Park SB, Whittington D, Sheffels P. New insights into the mechanism of methoxyflurane nephrotoxicity and implications for anesthetic development (part 1): identification of the nephrotoxic metabolic pathway. Anesthesiology. 2006;105(4):726-736.

8. Kharasch ED, Schroeder JL, Liggitt HD, Ensign D, Whittington D. New insights into the mechanism of methoxyflurane nephrotoxicity and implications for anesthetic development (part 2): identification of nephrotoxic metabolites. Anesthesiology. 2006;105(4):737-745.

9. Mazze RI, Trudell JR, Cousins MJ. Methoxyflurane metabolism and renal dysfunction: clinical correlation in man. Anesthesiology. 1971;35(3):247-252.

10. Desmond JW. Methoxyflurane nephrotoxicity. Can Anaesth Soc J. 1974;21(3):294-307.

11. Jones NO. Methoxyflurane nephrotoxicity: a review and a case report. Can Anaesth Soc J. 1972;19(2):152-159.

12. Urgena RB, Gergis SD. Nephrotoxicity from methoxyflurane anaesthesia: a 6-year retrospective study. Br J Anaesth. 1973;45(4): $358-362$.
13. US Federal Register. Determination that Penthrane (methoxyflurane) inhalation liquid, 99.9 percent, was withdrawn from sale for reasons of safety or effectiveness. Available from: https:/www.federalregister. gov/documents/2005/09/06/05-17559/determination-that-penthranemethoxyflurane-inhalation-liquid-999-percent-was-withdrawn-fromsale. Accessed July 19, 2018.

14. Australian Therapeutic Goods Administration Approved Product Information for Penthrox; 2016. Available from: https:/www.ebs.tga. gov.au/ebs/picmi/picmirepository.nsf/PICMI?OpenForm \&t=pi\&q=m ethoxyflurane. Accessed July 19, 2018.

15. New Zealand Datasheet for Penthrox; 2017. Available from: http:// www.medsafe.govt.nz/profs/datasheet/p/penthroxinh.pdf. Accessed July 19, 2018.

16. Penthrox $®$ Summary of Product Characteristics. Available from: https:// www.medicines.org.uk/emc/medicine/31391. Accessed July 19, 2018.

17. Medical Developments International. European Penthrox ${ }^{\circledR}$ Update, 12 August 2016. Available from: http://www.medicaldev.com/wpcontent/uploads/2016/08/ASX-Announcement_European-PenthroxUpdate_120816.pdf. Accessed July 19, 2018.

18. Coffey F, Dissmann P, Mirza K, Lomax M. Methoxyflurane analgesia in adult patients in the Emergency Department: a subgroup analysis of a randomized, double-blind, placebo-controlled study (STOP). $A d v$ Ther. 2016;33(11):2012-2031.

19. Mclennan JV. Is methoxyflurane a suitable battlefield analgesic? $J R$ Army Med Corps. 2007;153(2):111-113.

20. Australian and New Zealand College of Anaesthetists and Faculty of Pain Medicine. Acute Pain Management: Scientific Evidence. 4th ed 2015. Available from: https:/www.clinicalguidelines.gov.au/ portal/2505/acute-pain-management-scientific-evidence. Accessed July 19, 2018.

21. ACT Ambulance Service. Clinical Management Guidelines 2: Pain Management. July 2017. Available from: http://cdn.esa.act.gov.au/ wp-content/uploads/CMG-2-PAIN-MANAGEMENT-July-2017.pdf. Accessed July 19, 2018.

22. Queensland Ambulance Service. Drug Therapy Protocols: Methoxyflurane. April 2018. Available from: https://www.ambulance.qld.gov. au/docs/clinical/dtprotocols/DTP_Methoxyflurane.pdf. Accessed July 19, 2018.

23. St John Ambulance Australia (Western Australia). Clinical Practice Guidelines for Ambulance Care in Western Australia, Version 11. Available from: http:/www.fair-go.com/docs/Clinical\%20Practice\%20Guidelines\%20V11\%2022.07.11.pdf. Accessed July 19, 2018.

24. Ambulance Victoria. Clinical Practice Guidelines for Ambulance and MICA Paramedics. Available from: http://ambulance.vic.gov.au/ paramedics/clinical-practice-guidelines. Accessed July 19, 2018.

25. Coffey F, Wright J, Hartshorn S, et al. STOP!: a randomised, doubleblind, placebo-controlled study of the efficacy and safety of methoxyflurane for the treatment of acute pain. Emerg Med J. 2014;31(8):613-618.

26. Buntine P, Thom O, Babl F, Bailey M, Bernard S. Prehospital analgesia in adults using inhaled methoxyflurane. Emerg Med Australas. 2007;19(6):509-514.

27. Middleton PM, Simpson PM, Sinclair G, Dobbins TA, Math B, Bendall JC. Effectiveness of morphine, fentanyl, and methoxyflurane in the prehospital setting. Prehosp Emerg Care. 2010;14(4):439-447.

28. Gillis M, Keirens A, Steinkamm C, Verbelen J, Muysoms W, Reynders N. The use of methoxyflurane (Penthrox) in the emergency department. Reg Anesth Pain Med. 2008;33(Suppl 1):e247.

29. Konkayev AK. Evaluation of clinical effectiveness of inhalatory analgesic "Penthrox" for pain relief in ankle injuries. Arch Balkan Med Union. 2013;48:239-243.

30. Oxer HF, Wilkes G. Methoxyflurane is a safe, easy, effective analgesic for prehospital pain relief. Prehosp Disast Med. 2007;22:s77.

31. Lim KJH, Koh ZX, Zafirah NA. Clinical evaluation of Penthrox ${ }^{\circledR}$ (methoxyflurane) and tramadol for the Singapore Emergency Ambulance Service. Abstract presented at the Society for Emergency Medicine in Singapore Annual Scientific Meeting; February 27-28, 2016; Singapore. 
32. Babl F, Barnett P, Palmer G, Oakley E, Davidson A. A pilot study of inhaled methoxyflurane for procedural analgesia in children. Paediatr Anaesth. 2007;17(2):148-153.

33. Babl FE, Jamison SR, Spicer M, Bernard S. Inhaled methoxyflurane as a prehospital analgesic in children. Emerg Med Australas. 2006;18(4):404-410.

34. Bendall JC, Simpson PM, Middleton PM. Effectiveness of prehospital morphine, fentanyl, and methoxyflurane in pediatric patients. Prehosp Emerg Care. 2011;15(2):158-165.

35. Chin R, Maccaskill M, Browne G. A randomised control trial of inhaled methoxyflurane pain relief, in children with upper limb fracture. J Paediatr Child Health. 2002;38:A13.

36. Blair HA, Frampton JE. Methoxyflurane: a review in trauma pain. Clin Drug Investig. 2016;36(12):1067-1073.

37. Blair HA, Frampton JE. Methoxyflurane inhalation vapour in trauma pain: a profile of its use in the EU. Drugs Therapy Perspect. 2017;33(9):403-408.

38. Bijur PE, Latimer CT, Gallagher EJ. Validation of a verbally administered numerical rating scale of acute pain for use in the emergency department. Acad Emerg Med. 2003;10(4):390-392.

39. Todd KH, Funk KG, Funk JP, Bonacci R. Clinical significance of reported changes in pain severity. Ann Emerg Med. 1996;27(4):485-489.

40. Gallagher EJ, Liebman M, Bijur PE. Prospective validation of clinically important changes in pain severity measured on a visual analog scale. Ann Emerg Med. 2001;38(6):633-638.

41. Hoffman GA, Harrington A, Fields HL. Pain and the placebo: what we have learned. Perspect Biol Med. 2005;48(2):248-265.

42. Porter KM, Siddiqui MK, Sharma I, Dickerson S, Eberhardt A. Management of trauma pain in the emergency setting: low-dose methoxyflurane or nitrous oxide? A systematic review and indirect treatment comparison. J Pain Res. 2018;11:11-21.

43. Spruyt O, Westerman D, Milner A, Bressel M, Wein S. A randomised, double-blind, placebo-controlled study to assess the safety and efficacy of methoxyflurane for procedural pain of a bone marrow biopsy. BMJ Support Palliat Care. 2014;4(4):342-348.

44. Gaskell AL, Jephcott CG, Smithells JR, Sleigh JW. Self-administered methoxyflurane for procedural analgesia: experience in a tertiary Australasian centre. Anaesthesia. 2016;71(4):417-423.

45. Grummet J, Huang S, Konstantatos A, Frydenberg M. The "green whistle": a novel method of analgesia for transrectal prostate biopsy. BJU Int. 2012;110(Suppl 4):85-88.

46. Huang S, Pepdjonovic L, Konstantatos A, Frydenberg M, Grummet J. Penthrox alone versus Penthrox plus periprostatic infiltration of local analgesia for analgesia in transrectal ultrasound-guided prostate biopsy. ANZ J Surg. 2016;86(3):139-142.

47. Lee $\mathrm{C}$, Woo HH. Penthrox inhaler analgesia in transrectal ultrasoundguided prostate biopsy. ANZ J Surg. 2015;85(6):433-437.

48. Moss A, Parrish FJ, Naidoo P, et al. Self-administered, inhaled methoxyflurane improves patient comfort during nasoduodenal intubation for computed tomography enteroclysis for suspected small bowel disease: a randomized, double-blind, placebo-controlled trial. Clin Radiol. 2011;66(2):125-131.

49. Nguyen NQ, Toscano L, Lawrence M, et al. Patient-controlled analgesia with inhaled methoxyflurane versus conventional endoscopistprovided sedation for colonoscopy: a randomized multicenter trial. Gastrointest Endosc. 2013;78(6):892-901.

50. Nguyen NQ, Toscano L, Lawrence M, et al. Portable inhaled methoxyflurane is feasible and safe for colonoscopy in subjects with morbid obesity and/or obstructive sleep apnea. Endosc Int Open. 2015;3(5):E487-E493.

51. Wasiak J, Mahar PD, Paul E, Menezes H, Spinks AB, Cleland H. Inhaled methoxyflurane for pain and anxiety relief during burn wound care procedures: an Australian case series. Int Wound J. 2014;11(1):74-78.
52. Anwari JS, Khalil L, Terkawi AS. Efficacy of the methoxyflurane as bridging analgesia during epidural placement in laboring parturient. Saudi J Anaesth. 2015;9(4):370-375.

53. Jephcott C, Grummet J, Nguyen N, Spruyt O. A review of the safety and efficacy of inhaled methoxyflurane as an analgesic for outpatient procedures. Br J Anaesth. 2018;120(5):1040-1048.

54. Dayan AD. Analgesic use of inhaled methoxyflurane: evaluation of its potential nephrotoxicity. Hum Exp Toxicol. 2016;35(1):91-100.

55. Jacobs IG. Health effects of patients given methoxyflurane in the prehospital setting: a data linkage study. Open Emerg Med J. 2010;3:7-13.

56. Australian Government Department of Health Therapeutic Goods Administration. Database of Adverse Event Notifications (DAEN). Available from: https://www.tga.gov.au/database-adverse-eventnotifications-daen. Accessed July 19, 2018.

57. Johnston S, Wilkes GJ, Thompson JA, Ziman M, Brightwell R. Inhaled methoxyflurane and intranasal fentanyl for prehospital management of visceral pain in an Australian ambulance service. Emerg Med J. 2011;28(1):57-63.

58. Oxer HF. Effects of Penthrox $®$ (methoxyflurane) as an analgesic on cardiovascular and respiratory functions in the pre-hospital setting. $J$ Mil Veterans Health. 2016;24:14-20.

59. O'Rourke KM, Mcmaster S, Lust KM. A case of hepatitis attributable to repeated exposure to methoxyflurane during its use for procedural analgesia. Med J Aust. 2011;194(8):423-424.

60. Frangos J, Mikkonen A, Down C. Derivation of an occupational exposure limit for an inhalation analgesic methoxyflurane (Penthrox $\left({ }^{\circledR}\right)$. Regul Toxicol Pharmacol. 2016;80:210-225.

61. Ruff R, Kerr S, Kerr D, Zalcberg D, Stevens J. Occupational exposure to methoxyflurane administered for procedural sedation: an observational study of 40 exposures. Br J Anaesth. 2018;120(6):1435-1437.

62. de Francisco CP. Pentrane dependence: a case report. Br J Psychiatry. 1971;119(553):609-610.

63. Min KW, Cain GD, Sabel JS, Gyorkey F. Methoxyflurane hepatitis. South Med J. 1977;70(11):1363-1364.

64. Klemmer PJ, Hadler NM. Subacute fluorosis: a consequence of abuse of an organofluoride anesthetic. Ann Intern Med. 1978;89(5 Pt 1):607-611.

65. Okuno T, Takeda M, Horishi M, Okanoue T, Takino T. Hepatitis due to repeated inhalation of methoxyflurane in subanaesthetic concentrations. Can Anaesth Soc J. 1985;32(1):53-55.

66. Novak MA, Roth AS, Levine MR. Calcium oxalate retinopathy associated with methoxyflurane abuse. Retina. 1988;8(4):230-236.

67. Brennan RP, Pearlstein AE, Miller SA. Computed tomography of the kidneys in a patient with methoxyflurane abuse. J Comput Assist Tomogr. 1988;12(1):155-156.

68. Australian Government National Health and Medical Research Council. Emergency care acute pain management manual. 2011. Available from: https://www.nhmrc.gov.au/guidelines-publications/cp 135 . Accessed July 19, 2018.

69. The College of Emergency Medicine. Management of pain in adults 2014. Available from: https://www.rcem.ac.uk/docs/College $\% 20$ Guidelines/5w.\%20Management $\% 20$ of\%20Pain\%20in\%20Adults $\% 20$ (Revised\%20December\%202014).pdf. Accessed July 19, 2018.

70. Berben SA, Meijs TH, van Dongen RT, et al. Pain prevalence and pain relief in trauma patients in the Accident \& Emergency department. Injury. 2008;39(5):578-585.

71. Pierik JG, Ijzerman MJ, Gaakeer MI, et al. Pain management in the emergency chain: the use and effectiveness of pain management in patients with acute musculoskeletal pain. Pain Med. 2015;16(5):970-984.

72. Motov SM, Khan AN. Problems and barriers of pain management in the emergency department: are we ever going to get better? J Pain Res. 2008;2:5-11.

73. Carter D, Sendziuk P, Eliott JA, Braunack-Mayer A. Why is pain still under-treated in the emergency department? Two new hypotheses. Bioethics. 2016;30(3):195-202. 
74. Pierik JGJ, Ijzerman MJ, Gaakeer MI, Vollenbroek-Hutten MMR, Doggen CJM. Painful discrimination in the emergency department: risk factors for underassessment of patients' pain by nurses. $J$ Emerg Nurs. 2017;43(3):228-238.

75. Albrecht E, Taffe P, Yersin B, Schoettker P, Decosterd I, Hugli O. Undertreatment of acute pain (oligoanalgesia) and medical practice variation in prehospital analgesia of adult trauma patients: a $10 \mathrm{yr}$ retrospective study. Br J Anaesth. 2013;110(1):96-106.

76. Thomas D, Kircher J, Plint AC, et al. Pediatric pain management in the emergency department: the Triage nurses' perspective. J Emerg Nurs. 2015;41(5):407-413.

77. Dißmann PD, Maignan M, Cloves PD, Gutierrez Parres B, Dickerson $\mathrm{S}$, Eberhardt A. A review of the burden of trauma pain in emergency settings in Europe. Pain Ther. Epub 2018 Jun 02.

78. Rickard C, O’Meara P, Mcgrail M, Garner D, Mclean A, Le Lievre P. A randomized controlled trial of intranasal fentanyl vs intravenous morphine for analgesia in the prehospital setting. Am J Emerg Med. 2007;25(8):911-917.

79. Crellin D, Ling RX, Babl FE. Does the standard intravenous solution of fentanyl ( $50 \mathrm{microg} / \mathrm{mL}$ ) administered intranasally have analgesic efficacy? Emerg Med Australas. 2010;22(1):62-67.

80. Hansen MS, Dahl JB. Limited evidence for intranasal fentanyl in the emergency department and the prehospital setting: a systematic review. Dan Med J. 2013;60(1):A4563.

81. Murphy A, O'Sullivan R, Wakai A, et al. Intranasal fentanyl for the management of acute pain in children. Cochrane Database Syst Rev. 2014;10(10):CD009942.

82. Karlsen AP, Pedersen DM, Trautner S, Dahl JB, Hansen MS. Safety of intranasal fentanyl in the out-of-hospital setting: a prospective observational study. Ann Emerg Med. 2014;63(6): 699-703.

83. Yeaman F, Oakley E, Meek R, Graudins A. Sub-dissociative dose intranasal ketamine for limb injury pain in children in the emergency department: a pilot study. Emerg Med Australas. 2013;25(2): $161-167$.

84. Andolfatto G, Willman E, Joo D, et al. Intranasal ketamine for analgesia in the emergency department: a prospective observational series. Acad Emerg Med. 2013;20(10):1050-1054.

85. Yeaman F, Meek R, Egerton-Warburton D, Rosengarten P, Graudins A. Sub-dissociative-dose intranasal ketamine for moderate to severe pain in adult emergency department patients. Emerg Med Australas. 2014;26(3):237-242.

86. Graudins A, Meek R, Egerton-Warburton D, Oakley E, Seith R. The PICHFORK (Pain in Children Fentanyl or Ketamine) trial: a randomized controlled trial comparing intranasal ketamine and fentanyl for the relief of moderate to severe pain in children with limb injuries. Ann Emerg Med. 2015;65(3):248-254.

87. Reynolds SL, Studnek JR, Bryant K, et al. Study protocol of a randomised controlled trial of intranasal ketamine compared with intranasal fentanyl for analgesia in children with suspected, isolated extremity fractures in the paediatric emergency department. $B M J$ Open. 2016;6(9):e012190.

88. Peura DA. Gastrointestinal safety and tolerability of nonselective nonsteroidal anti-inflammatory agents and cyclooxygenase-2-selective inhibitors. Cleve Clin J Med. 2002;69(Suppl 1):SI31-SI39.
89. Dijkstra BM, Berben SA, van Dongen RT, Schoonhoven L. Review on pharmacological pain management in trauma patients in (pre-hospital) emergency medicine in the Netherlands. Eur J Pain. 2014;18(1):3-19.

90. Entonox Summary of Product Characteristics. Available from: http://www.mhra.gov.uk/spc-pil/?prodName=ENTONOX\%20 MEDICIN A L \% 20 G A S \& s u b s N a m e = N I T ROU S \% 20 OXIDE\&pageID=SecondLevel. Accessed July 19, 2018.

91. Nolan JP, Baskett PJF. Analgesia and anaesthesia. Skinner DV, editor. Cambridge, UK: Cambridge Textbook of Accident and Emergency Medicine. Cambridge University Press. 1997:188-189.

92. Komessaroff D. Pre-hospital pain relief: Penthrane or Entonox. Aust J Emerg Care. 1995;2:28-29.

93. Tveita T, Thoner J, Klepstad P, Dale O, Jystad A, Borchgrevink PC. A controlled comparison between single doses of intravenous and intramuscular morphine with respect to analgesic effects and patient safety. Acta Anaesthesiol Scand. 2008;52(7):920-925.

94. Ducassé JL, Siksik G, Durand-Béchu M, et al. Nitrous oxide for early analgesia in the emergency setting: a randomized, double-blind multicenter prehospital trial. Acad Emerg Med. 2013;20(2):178-184.

95. Chaplin S, Zeppetella G. Instanyl: intranasal fentanyl for treating breakthrough pain. Prescriber. 2010;21(6):40-42.

96. Nguyen NQ, Burgess J, Debreceni TL, Toscano L. Psychomotor and cognitive effects of 15-minute inhalation of methoxyflurane in healthy volunteers: implication for post-colonoscopy care. Endosc Int Open. 2016;4(11):E1171-E1177.

97. Sokoloff C, Daoust R, Paquet J, Chauny JM. Is adequate pain relief and time to analgesia associated with emergency department length of stay? A retrospective study. BMJ Open. 2014;4(3):e004288.

98. Oxford League Table of Analgesics in Acute Pain. Available from: http://www.jr2.ox.ac.uk/bandolier/booth/painpag/Acutrev/Analgesics/ Leagtab.html. Accessed July 19, 2018.

99. Mundipharma Pharmaceuticals SL. A phase IIIb open randomized clinical trial to compare pain relief between methoxyflurane and standard of care for treating patients with trauma pain in Spanish emergency units. Available from: https://www.clinicaltrialsregister.eu/ ctr-search/trial/2017-000338-70/ES. EudraCT number 2017-00033870. Accessed July 19, 2018.

100. Borobia Pérez AM, Capilla Pueyo R, Casal Codesido JR, et al. InMEDIATE Group. Phase IIIb, open label randomised clinical trial to compare pain relief between methoxyflurane and standard of care for treating patients with trauma pain in Spanish Emergency Units (InMEDIATE): Study protocol. IBJ Clin Pharmacol. 2017;1:e008.

101. Mundipharma Pharmaceuticals srl. Efficacy and safety of methoxyflurane vaporized (PENTHROX $®$ ) in the treatment of acute trauma pain in pre-hospital setting and in the emergency department in Italy: a multicentre, randomized, controlled, open-label study. Available from: https://www.clinicaltrialsregister.eu/ctr-search/trial/2017-001565-25/ IT. EudraCT number 2017-001565-25. Accessed July 19, 2018.

102. Medical Developments International Limited. A randomised, doubleblind, multicentre, placebo controlled study to evaluate the safety and efficacy of methoxyflurane (PENTHROX $®$ ) for the treatment of acute pain in children and adolescents from 6 to less than 18 years of age (presenting to an Emergency Department with minor trauma). Available from: https://www.clinicaltrialsregister.eu/ctr-search/trial/2016-00429041/GB. EudraCT number 2016-004290-41. Accessed July 19, 2018.
Open Access Emergency Medicine

\section{Publish your work in this journal}

The Open Access Emergency Medicine is an international, peerreviewed, open access journal publishing original research, reports, editorials, reviews and commentaries on all aspects of emergency medicine. The manuscript management system is completely online and includes a very quick and fair peer-review system, which is all
Dovepress

easy to use. Visit http://www.dovepress.com/testimonials.php to read real quotes from published authors. 